\title{
The Main Channels of English Phonics Learning among Chinese School-age Children
}

\author{
Huanhuan $\operatorname{Ren}^{1, \mathrm{a}^{*}}$ and Chi Ma ${ }^{2, \mathrm{~b}}$ \\ ${ }^{1}$ Teaching and Research Institute of Foreign Languages, Bohai University, Jinzhou 121013, China \\ 2 Jinzhou Institute of Forestry Research, Jinzhou Forestry Bureau, Jinzhou 121013, China \\ arenhuanhuan2014@163.com, ${ }^{b}$ machi2014@tom.com
}

\section{Keywords: English Phonics; Main Channels; Chinese School-age Children}

\begin{abstract}
It's known that phonics is an important part of literacy instruction for native speakers. However, it's argued that problems of English phonics learning among Chinese school-age children lie in three areas of phonic learning, namely, less emphasis on phonics learning, mixed extra-curriculum training programs and overwhelming learning resources. The main channels of English phonics learning among Chinese school-age children are found in a wealth of forms: interactive Apps in smart devices, multi ROMs and videos, phonics-focused animated cartoons, series of phonics textbooks, picture books and leveled books, and courses provided by language training schools. It's hoped that this research provides a useful reference for future phonics instruction and learning practice among young English language students in China.
\end{abstract}

\section{Introduction}

There is a global trend toward the incorporation of phonics in EFL instruction among young English language learners[1]. It's suggested that that young EFL learners are shown the ability to learn a foreign language, and phonics are supposed to be taught systematically as part of a balanced and integrated English language program among EFL learners including Chinese young children[2]. How much do you know about the effectiveness and efficiency of phonics learning among Chinese school-age children? What type of dilemmas might be met by Chinese school-age children in the process of English phonics learning? Which resources pertaining to phonics learning are available to Chinese school-age children? Based on the critical analysis of the trend of English learning among Chinese school-age children, we attempt to find out problems of English phonics learning and main channels of English phonics learning among Chinese school-age children, so as to boost their success in English language learning. This paper is a summary of this research work, which hopefully provides a useful reference for future phonics instruction and learning practice among young language students in China.

\section{The Trend of English Learning among Chinese School-age Children}

The EFL Requirement of the Nation. Many countries in the world do not have a nationwide foreign-language mandate at any level of education, but China doesn't belong to this category[3]. China does have a national requirement for students to learn a foreign language in school out of strong requirements of economic and social development of the nation. With the rapid advancement of globalization, there is a big short of talents with ability in communicating with foreign partners or friends in English. It's concurred that Chinese learners are supposed to have compulsory language requirements in hope that people can be culturally diverse, and proficient in oral and written language. We can say learning a foreign language is a must in China. Along with native language Chinese, students begin studying their first foreign language English as a compulsory school subject at the age of nine when they are in the third year of primary school[4]. From then on, English is the most-studied subject learners have to work out at all education levels ranging from primary school, middle school, senior high school to college across almost all provinces and cities in China. Doors may open for a country like China with a mass of graduates knowledgeable in English language and proficient in multicultural communication. 
The EFL Focus of the Institute. All sorts of institutes are expected to take on the responsibility and mission to develop students' proficiency and appreciation for the knowledge and skills of English language. However, it's evident that institutes at all levels of education go much further than requirements. For example, although kindergartens are not obligated to offer English options to all students who are at ages of 3-6, the portion of preschool pupils studying it remains high across the country, even including cities less developed in China. This trend varies by cities. For example, as for big cities with dramatic development in China, there is a fad that children learn English as early as three years old when they show a formidable ability in distinguishing and memorizing English phonemes and mastering tones of English language[5]. Children there can have a variety of choices in accessing to eye-catching English enlightenment and training centers with native English speakers as instructors. So far it's shown that institutes ranging from early childhood education programs, nursery school, to early-years education in primary schools, have very high rates of offering English foreign language course work.

The EFL Attention of the Family. Not all children who claim to learn English language acquire it in school. English is more and more widely taught as a foreign language at home. Parents with strong English education conscious spare no efforts to develop the English language skills of their own kids. With the development and application of enabling digital technologies in China, parents today have no difficulties in entering into a large amount of quality English phonics materials and resources. Moreover, it should be figured out that resources provided can be learned together, or individually, since some are perfect are for use at home, and some for one-to-one teaching or small groups. In this respect, parents can find abundant help and support offered online or offline on how to learn and teach English by professional English language teachers. Sometimes parents are not only knowledge providers and skill trainers but also peer learners of their kids. In order to make kids' enthusiasm for learning high, learning with parents provides a meaningful start for kids for sure. The young age trend of learning English encourage parents to keep passionate about teaching kids to speak, read and write English and cultivating an appreciation for cultures of English-speaking countries.

\section{Problems of English Phonics Learning among Chinese School-age Children}

Less Emphasis on Phonics Learning. If asked what phonics is in China, fewer parents can get to know the exact meaning of it, even including parents with jobs relevant to English teaching. As for the question on importance and methods of phonics learning for young learners, more parents will be at lost. The paradox is that those parents are very conscious about their kids' English learning, if not anxious, but they just move far away from the pursuit of English phonics for their kids. A lot of parents don't even give a try to get to learn and understand the phonics, not alone educating their kids about phonics with the aid of multimedia such as videos or audios at home. Parents' ignorance of phonics is echoed with the "no care" attitude of educational institutes in regions. It's clear that all school-age children in China have to receive English class legitimately from the third year in primary school[6], but most the textbooks chosen only give much attention to international phonetic alphabet rather than phonics. The reason behind it is that instructors in educational institutes don't have the sufficient motivation to make reforms on English curriculum in primary school and thus fail to keep pace with the norm and trend of English education across the globe. It's especially true for instructors and educators in a mass of less-developed cities in China.

Mixed Extra-curriculum Training Programs. There has never been short of extra-curriculum training classes in China, so parents and children always have an abundance of choices on which English class to partake after school. In order to adapt to test-oriented education, most parents and children are in favor of English training classes with focus on transiting grammars and doing exercises for tests. It holds water for young English learners, even with pre-school kids included. Unfortunately, much ignorance is directed to phonics learning among younger English learners who are just at the best time receiving English language enlightenment with a large amount of accurate phonemes and sounds. With less popularity gained over phonics, fewer extra-curriculum training centers can offer an exceptional training program covering language, ideas and phonics, especially in less developed cities in China, 
where there are fewer native English speakers with proven techniques for teaching English as a foreign language. With the fast development of online education, Chinese parents recently do have a better chance to provide desired English education for learners on the Internet, but it still need time and courage for them to say farewell to traditional test-oriented education.

Overwhelming Learning Resources. In the time of information exploration, learning resources are everywhere and updated in a extremely fast speed. It's evident that learners are suffering from choosing among the overwhelming recourses. Parents and kids are faced with a large amount of information about phonics learning. If learners look at it further, those learning resources can be found in a wide range, and it's easy for parents and kids to get excited at the wonder found in high-quality learning resources especially originated and introduced from English native speaking countries. Most notably, the key point is to find out the proper resources suitable for kids and check out the way of making full advantage of the resources. It's proved that children have different learning styles. Visual learners learn better by seeing, auditory learners by listening, some learners by reading and writing, and kinesthetic learners with movement[7]. Then how to use all of these approaches to help every child realize his or her potential? There are no guide for parents and kids. It's obvious that explaining and figuring out the principles and wisdoms behind learning recourses so as to further promote parents' understanding of the phonics learning and boosting their ability of helping children in learning phonics, is much greater. With right phonics resources available, parents with no English background can still be successful in teaching their kids phonics at home for free.

\section{The Main Channels of English Phonics Learning among Chinese School-age Children}

Interactive Apps in Smart Devices. With the enabling information technology, phonics can be fun and engaging within multimedia devices such as smart phone, iPad, and laptop, to name just a few. Learning through various apps has become a new trend among language learners especially school-age children in China. Many apps introduce phonics using animated alphabets and even write each letter with strokes in right order. The child can trace over the letters, and apps can also check with writing with correct tracing shown in green and wrong tracing in red. More activities can be designed to help learners to focus on words that need practice. For example, children can drag the bubbles to their correct location to build the word shown in the picture. In this way, children are more likely to be successful in developing confidence and competence of mastering the rudiments of phonics in an efficient and practical method.

Multi ROMs and Videos. More phonics learning can be found in a wealth of resources in the forms of Multi ROMs and videos. With much fun, ROMs and videos provide helpful pronunciations of the target letters and sounds as well as activating computer-based learning skills. Learners can obtain access to the way of English fluency with a systematic presentation of the alphabet, vowel combinations, and consonant blends. Let's take Super Simple Phonics videos for example. Since learning the alphabet can be intimidating for any child, so Super Simple Phonics videos was designed to give young learners an "I can do it!" attitude toward letters and phonics. With that in mind, Super Simple Phonics videos have the follow features: simple, silly, memorable songs; easy-to follow mini audio lessons; "Karaoke" tracks; vocalization and easily recognizable vocabulary; fun, simple images[8]. It's believed that there are much things to be done with the help of the fun, no-pressure introduction to the English alphabet and phonics for Chinese school-age learners.

Phonics-focused Animated Cartoons. Students can work and learn in the comfort of their homes with the help of phonics-focused animated cartoons. Phonics-focused animated cartoons allow children the chance to further their learning experiences in a whole new way. Throughout the appealing plot of cartoons, children are encouraged to discover connections between English sounds and letters as well as understand an processing information from a wide range of sources. Cartoons about teaching phonics can be simple enough for a three-year-old beginning English learner but fun and appealing to older beginner as well. They are specially developed to give a head start in language learning to children from preschool and up. It's easy to find out that phonics kids are deeply attracted by the interesting characters and plots in cartoons, such as Alphablock, Word World, Wallykazam, Leap Frog, Word Girl, to name just a few. The best asset of phonics-focused animated cartoons is that they craftily disguise solid lessons 
in basic literacy skills as delightful stories and are all in ways that feel nothing to kids like the quality lessons they actually are.

Series of Phonics Textbooks. A large amount of phonics textbooks are designed to teach the knowledge of phonics. They emphasize the key phonics that young learners need to understand, for example, the relationship between letters and sounds. The scope and sequence of each textbook is elaborately developed to offer an exceptionally strong skills in phonics and vocabulary acquisition, and there are even many phonics series especially developed for young EFL or ESL learners. All core language is recycled regularly throughout the textbook. With the full-color illustrations and vast assortment of activities such as rhyming chants, fun puzzles, draw and color, letters in action and so on in each until, learners are more likely to engage into a joyful and efficient learning experience. Besides, phonics cards, words flashcards, workbook and hopefully digital resources can be provided along with phonics series, in hope that interests and competence of learners can be acquired and remained at the maximum whilst learners are building and fostering listening, reading, and writing skills.

Picture Books and Leveled Books. Parents and teachers may find paths to help students practice their English phonics skills with picture books and leveled books. Phonics-oriented readers present additional support and give sample opportunities for students who need or desire more practice about reading the new letters and sounds. Carefully controlled, reader series provides students with the ability to see the letters and words they just learned and incorporated into fun and exciting stories they are sure to enjoy over and over. Moreover, amazing and remarkable illustrators lend their talents in bringing different stories and tales to color and life. And activities designed at the end of serial readers can aid students in learning to read books and increasing their receptive knowledge of English structures at the same time. It's hoped that English language learners start to learn to really read, not just memorize words and sounds. Without doubt, decoding stories and phonics readers encourage school-age learners to lead independent reading and take fun in reading experience as well.

Courses Provided by Language Training Schools. English phonics training process may be easy and relaxing for parents going for professional foreign language schools online or offline, since parents might be greatly freed from teaching children English phonics with material at home. It's believed that doors open as children partake in a wide range of language sources. There are a lot choices that can be made by parents and instructors concerning different courses. Some of the courses are long-term synthetic courses, featuring a clear grammar-based curriculum alongside parallel syllabi in skills and phonics, whereas some of the courses are short-term specialized courses with a strong focus on phonics particularly at the time when summer or winter vacations occur. All in all, various learning elements such as interests, levels and styles of English learners should be considered by instructors and parents when choosing a suitable language training school for young children in China.

\section{Conclusion}

It's known that phonics is an important part of literacy instruction for native speakers. However, it's argued that problems of English phonics learning among Chinese school-age children lie in three areas of phonic learning, namely, less emphasis on phonics learning, mixed extra-curriculum training programs and overwhelming learning resources. The main channels of English phonics learning among Chinese school-age children are found in a wealth of forms: interactive Apps in smart devices, multi ROMs and videos, phonics-focused animated cartoons, series of phonics textbooks, picture books and leveled books, and courses provided by language training schools. It's hoped that this research provides a useful reference for future phonics instruction and learning practice among young English language students in China.

\section{Acknowledgements}

This work is part of the project of On Intrinsic Logics, Main Implications and Intervetnion Reserach of English Phonics Enlightenment among Chinese School-age Children. This research was supported by the fund of Liaoning Planning of Philosophy and Social Science (Project No. L17CYY005). 


\section{References}

[1] H.H. Ren, C. Ma. Study on the practice of phonics in English vocabulary teaching for primary school students. In J. Wang, N. Xin and H. Y. Zhou (eds.). Advances in Computer Science Research v 59. Paris: Atlantis Press. December 2016, pp.1095-1099.

[2] H. H. Ren, C. Ma. The impact of Phonics instruction on pre-school learners' development in English language course. In J. Wang, N. Xin and H. Y. Zhou (eds.). Advances in Computer Science Research v 59. Paris: Atlantis Press. December 2016, pp.674-679

[3][4][6] J. Walker. The world's English mania. TED. 2009. Retrieved from the information on https://www.ted.com/talks/jay_walker_on_the_world_s_english_mania

[5] Cognitive Stages for Child Development, Retrieved from the information on http://www.learningrx.com/cognitive-stages-for-child-development.htm

[7] J. Penn. Family and Friends: Teacher's Book. Oxford University Press, 2009.

[8] D. Thagard, T. McDonald. Super Simple Phonics. Knock Knock English, 2008.

[9] Peng L, Xiaoping Z. Social Stratification and Cooperative Behavior in Spatial Prisoners' Dilemma Games [J]. PLOS ONE, 2015, 10(7): e0131005. 